\title{
Height and Weight at Menarche and a Hypothesis of Menarche
}

\author{
ROSE E. FRISCH, and ROGER REVELLE \\ From the Harvard Center for Population Studies, Cambridge, Mass., U.S.A.
}

\begin{abstract}
Frisch, R. E., and Revelle, R. (1971). Archives of Disease in Childhood, 46, 695. Height and weight at menarche and a hypothesis of menarche. Height and weight at menarche were estimated by interpolation of longitudinal growth data for 181 girls. Mean weight at menarche, about $48 \mathrm{~kg}$, does not change as menarcheal age increases, whereas mean height increases significantly. Early and late menarcheal girls gain the same amount of height, about $22 \mathrm{~cm}$, and the same amount of weight, about $17 \mathrm{~kg}$, in the interval from the initiation of the adolescent spurt to menarche, though late maturers grow at slower rates during the spurt, including the year of menarche. A hypothesis of a direct relation between a critical weight and menarche is proposed. Such an interaction would explain the delaying effect of malnutrition on menarche and the secular trend to an earlier menarche.
\end{abstract}

Though there are many general observations that girls at menarche are taller and heavier than those of the same age who have not achieved menarche (Tanner, 1962), there are no published data on actual height and weight at menarche, as far as we know. In a preliminary report we gave data for height and weight at menarche obtained for each girl by interpolation of the data of three longitudinal growth studies. At menarche, the mean weight of early and late menarcheal girls did not differ, whereas late menarcheal girls were significantly taller than girls with early menarche (Frisch and Revelle, 1970).

Menarche occurs after the initiation of the adolescent growth spurt and the attainment of the maximum rates of growth in height and weight (Frisch and Revelle, 1969b; Simmons and Greulich, 1943). Our analysis of the same longitudinal growth studies for the height and weight of each child at the time of spurt initiation (Frisch and Revelle, 1971), and the maximum rates of growth (Frisch and Revelle, 1969b) also showed that the mean weight of early and late maturing girls did not differ at each of these events, whereas late maturers were significantly taller at each event.

These results account for the many observations that early maturers have more weight for height before, and throughout the adolescent spurt, including the year of menarche (Tanner, 1962).

Received 16 March 1971.
It was unexpected, however, that three of the major events of adolescence were related to an unchanging mean weight.

This paper gives additional findings of our analysis of height and weight at menarche as a function of age of menarche. A hypothesis of menarche and an explanation of the secular trend to an earlier menarche (Tanner, 1966; Marshall and Tanner, 1968) are proposed.

\section{Method}

We are grateful to Dr. Robert McCammon and Dr. Charlotte Hansman of the University of Colorado Medical Center, Denver, Colorado, for transcripts of the growth data of the Child Research Council (CRC), and to Dr. Isabelle Valadian and Dr. Robert Reed of the Harvard School of Public Health (HSPH) for making available the data from the Longitudinal Studies of Child Health and Development, Harvard School of Public Health. The data of the Berkley Guidance Study (BGS) are published in entirety (Tuddenham and Snyder, 1954).

The three growth studies are comparable. Height and weight measurements from birth to age 18 , collected in the years from 1929 to 1950 , were given for halfyearly (CRC, BGS, HSPH up to age 11) and yearly (HSPH, after age 11) intervals. The socioeconomic status of the parents was average (HSPH) (Stuart, Reed et al., 1959), and above-average (BGS and CRC) (Tuddenham and Snyder, 1954; Dunlop, 1943).

Age of menarche was recorded to the tenth of a year in the CRC and BGS studies and in months in the 
HSPH study; the latter were converted to years and tenths of a year. Height and weight at menarche were estimated by interpolation to the nearest tenth of a centimetre and tenth of a kilogram, respectively, for 181 girls of the 201 girls in the studies. Interpolation was within a half-year interval for $71 \%$ of the girls, and within a year interval for the remainder. Of the 20 girls omitted, 3 had missing menarcheal dates; 3 (2 BGS, 1 HSPH) had weights at menarche greater than $70 \mathrm{~kg}$, which a study of the distribution of menarcheal weights showed to be abnormal; and 14 were discarded (12 HSPH, 2 CRC) because of growth data intervals greater than a year at the menarcheal year. The means of age of men- arche and height and weight at age 18 of the discarded girls did not differ significantly from those remaining in the study.

The height and weight gained and the time intervals from the initiation of the adolescent height and weight spurts to menarche were found for each of 169 girls for whom data for both initiation of the spurt and menarcheal height and weight were available.

\section{Result}

The mean age of all girls at menarche is $12 \cdot 9 \pm$ 0.09 years. Their mean weight at menarche is

TABLE I

Mean Height $\left(H_{m c h}\right)$ and Mean Weight $\left(W_{m c h}\right)$ at Menarche, and Height $\left(H_{18}\right)$ and Weight $\left(W_{18}\right)$ at Age 18 of CRC, BGS, and HSPH Girls Grouped According to Age of Menarche, and For All Subjects

\begin{tabular}{|c|c|c|c|c|c|c|c|}
\hline $\begin{array}{c}\text { Menarcheal } \\
\text { Age Group (yr) }\end{array}$ & $\begin{array}{l}\text { Growth } \\
\text { Study }\end{array}$ & No. & $\begin{array}{l}\text { Mean Age } \\
(\mathbf{y r}) \mathbf{M c h}\end{array}$ & $\begin{array}{l}\text { Mean } \mathrm{H}_{\text {mch }} \\
(\mathrm{cm})\end{array}$ & $\underset{(\mathbf{k g})}{\operatorname{Mean}} \mathbb{W}_{\text {mch }}$ & $\underset{(\mathrm{cm})}{\operatorname{Mean} \mathrm{H}_{18}}$ & $\underset{(\mathrm{kg})}{\operatorname{Mean} \mathbf{W}_{18}}$ \\
\hline \multirow[t]{2}{*}{$\begin{array}{l}\text { Up to and including } \\
11.9\end{array}$} & $\begin{array}{l}\text { CRC } \\
\text { BGS } \\
\text { HSPH }\end{array}$ & $\begin{array}{l}10 \\
15 \\
10\end{array}$ & $\begin{array}{c}11 \cdot 3 \\
\text { SD } \\
11 \cdot 4 \\
\text { SD } \\
11 \cdot 5 \\
\text { SD }\end{array}$ & $\begin{array}{r}155 \cdot 0 \\
7 \cdot 6 \\
157 \cdot 8 \\
4 \cdot 6 \\
155 \cdot 5 \\
4 \cdot 5\end{array}$ & $\begin{array}{r}45 \cdot 8 \\
4 \cdot 1 \\
50 \cdot 0 \\
6 \cdot 3 \\
46 \cdot 9 \\
7 \cdot 1\end{array}$ & $\begin{array}{r}164 \cdot 9 \\
7 \cdot 7 \\
167 \cdot 9 \\
6 \cdot 3 \\
163 \cdot 8 \\
4 \cdot 8\end{array}$ & $\begin{array}{r}58 \cdot 3 \\
10 \cdot 8 \\
62 \cdot 7 \\
7 \cdot 7 \\
57 \cdot 0 \\
6 \cdot 7\end{array}$ \\
\hline & Total & 35 & $11 \cdot 4$ & $\begin{array}{r}156 \cdot 4 \\
5 \cdot 7\end{array}$ & $\begin{array}{r}47 \cdot 9 \\
6 \cdot 5\end{array}$ & $\begin{array}{r}165 \cdot 9 \\
6 \cdot 5\end{array}$ & $\begin{array}{r}59 \cdot 5 \\
8 \cdot 9\end{array}$ \\
\hline \multirow[t]{2}{*}{$12 \cdot 0-12 \cdot 9$} & $\begin{array}{l}\text { CRC } \\
\text { BGS } \\
\text { HSPH }\end{array}$ & $\begin{array}{l}17 \\
23 \\
20\end{array}$ & $\begin{array}{c}12 \cdot 3 \\
\text { SD } \\
12 \cdot 5 \\
\text { SD } \\
12 \cdot 5 \\
\text { SD }\end{array}$ & $\begin{array}{r}159 \cdot 1 \\
5 \cdot 5 \\
157 \cdot 2 \\
5 \cdot 0 \\
157 \cdot 9 \\
6 \cdot 2\end{array}$ & $\begin{array}{r}49 \cdot 1 \\
8 \cdot 3 \\
49 \cdot 8 \\
7 \cdot 0 \\
47 \cdot 2 \\
6 \cdot 9\end{array}$ & $\begin{array}{r}167 \cdot 5 \\
4 \cdot 6 \\
164 \cdot 9 \\
5 \cdot 2 \\
165 \cdot 3 \\
6 \cdot 3\end{array}$ & $\begin{array}{r}60 \cdot 0 \\
9 \cdot 1 \\
59 \cdot 3 \\
7 \cdot 0 \\
56 \cdot 0 \\
6 \cdot 6\end{array}$ \\
\hline & Total & 60 & $\begin{array}{l}12 \cdot 4 \\
S D\end{array}$ & $\begin{array}{r}158 \cdot 0 \\
5 \cdot 6\end{array}$ & $\begin{array}{r}48 \cdot 7 \\
7 \cdot 4\end{array}$ & $\begin{array}{r}165 \cdot 8 \\
5 \cdot 5\end{array}$ & $\begin{array}{r}58 \cdot 4 \\
7 \cdot 7\end{array}$ \\
\hline \multirow[t]{2}{*}{$13 \cdot 0-13 \cdot 9$} & $\begin{array}{l}\text { CRC } \\
\text { BGS } \\
\text { HSPH }\end{array}$ & $\begin{array}{l}19 \\
18 \\
17\end{array}$ & $\begin{array}{c}13 \cdot 3 \\
\text { SD } \\
13 \cdot 3 \\
\text { SD } \\
13 \cdot 4 \\
\text { SD }\end{array}$ & $\begin{array}{r}159 \cdot 1 \\
7 \cdot 3 \\
161 \cdot 2 \\
7 \cdot 6 \\
156 \cdot 8 \\
7 \cdot 6\end{array}$ & $\begin{array}{r}47 \cdot 1 \\
6 \cdot 1 \\
49 \cdot 2 \\
7 \cdot 3 \\
45 \cdot 1 \\
6 \cdot 8\end{array}$ & $\begin{array}{r}165 \cdot 4 \\
5 \cdot 9 \\
167 \cdot 6 \\
5 \cdot 9 \\
162 \cdot 5 \\
8 \cdot 0\end{array}$ & $\begin{array}{r}55 \cdot 8 \\
6 \cdot 0 \\
57 \cdot 8 \\
6 \cdot 3 \\
54 \cdot 1 \\
7 \cdot 1\end{array}$ \\
\hline & Total & 54 & $\begin{array}{l}13 \cdot 4 \\
\text { SD }\end{array}$ & $\begin{array}{r}159 \cdot 1 \\
7 \cdot 4\end{array}$ & $\begin{array}{r}47 \cdot 2 \\
6 \cdot 8\end{array}$ & $\begin{array}{r}165 \cdot 2 \\
7 \cdot 0\end{array}$ & $\begin{array}{r}55 \cdot 9 \\
6 \cdot 5\end{array}$ \\
\hline \multirow[t]{2}{*}{$14 \cdot 0$ and over } & $\begin{array}{l}\text { CRC } \\
\text { BGS } \\
\text { HSPH }\end{array}$ & $\begin{array}{r}16 \\
9 \\
17\end{array}$ & $\begin{array}{c}14 \cdot 3 \\
\text { SD } \\
14 \cdot 7 \\
\text { SD } \\
14 \cdot 4 \\
\text { SD }\end{array}$ & $\begin{array}{r}162 \cdot 6 \\
8 \cdot 1 \\
161 \cdot 3 \\
9 \cdot 5 \\
156 \cdot 4 \\
6 \cdot 7\end{array}$ & $\begin{array}{r}47 \cdot 5 \\
6 \cdot 4 \\
47 \cdot 5 \\
8 \cdot 4 \\
46 \cdot 0 \\
5 \cdot 2\end{array}$ & $\begin{array}{r}168 \cdot 0 \\
7 \cdot 7 \\
166 \cdot 0 \\
8 \cdot 7 \\
160 \cdot 9 \\
6 \cdot 2\end{array}$ & $\begin{array}{r}54 \cdot 7 \\
9 \cdot 0 \\
55 \cdot 3 \\
8 \cdot 3 \\
52 \cdot 2 \\
6 \cdot 1\end{array}$ \\
\hline & Total & 32 & $\stackrel{14 \cdot 5}{\text { SD }}$ & $\begin{array}{r}160 \cdot 9 \\
7 \cdot 9\end{array}$ & $\begin{array}{r}47 \cdot 2 \\
6 \cdot 8\end{array}$ & $\begin{array}{r}165 \cdot 8 \\
7 \cdot 9\end{array}$ & $\begin{array}{r}54 \cdot 3 \\
7 \cdot 9\end{array}$ \\
\hline \multirow[t]{2}{*}{ All subjects } & $\begin{array}{l}\text { CRC } \\
\text { BGS } \\
\text { HSPH }\end{array}$ & $\begin{array}{c}62 \\
\text { SD } \\
65 \\
\text { SD } \\
54 \\
\text { SD }\end{array}$ & $\begin{array}{c}13 \cdot 0^{\star} \\
1 \cdot 1 \\
12 \cdot 8 \\
1 \cdot 1 \\
12 \cdot 8 \\
0 \cdot 96\end{array}$ & $\begin{array}{r}159 \cdot 3 \\
7 \cdot 3 \\
159 \cdot 0 \\
6 \cdot 6 \\
156 \cdot 9 \\
6 \cdot 4\end{array}$ & $\begin{array}{r}47 \cdot 5 \\
6 \cdot 6 \\
49 \cdot 4 \\
7 \cdot 0 \\
46 \cdot 3 \\
6 \cdot 6\end{array}$ & $\begin{array}{r}166 \cdot 6 \\
6 \cdot 3 \\
166 \cdot 5 \\
6 \cdot 3 \\
163 \cdot 6 \\
6 \cdot 7\end{array}$ & $\begin{array}{r}57 \cdot 1 \\
8 \cdot 6 \\
59 \cdot 1 \\
7 \cdot 4 \\
55 \cdot 1 \\
6 \cdot 7\end{array}$ \\
\hline & Total & $\stackrel{181}{S D}$ & $\begin{array}{r}12 \cdot 9 \\
1 \cdot 2\end{array}$ & $\begin{array}{r}158 \cdot 5 \\
6 \cdot 8\end{array}$ & $\begin{array}{r}47 \cdot 8 \\
6 \cdot 9\end{array}$ & $\begin{array}{r}165 \cdot 6 \\
6 \cdot 6\end{array}$ & $\begin{array}{r}57 \cdot 1 \\
7 \cdot 8\end{array}$ \\
\hline
\end{tabular}

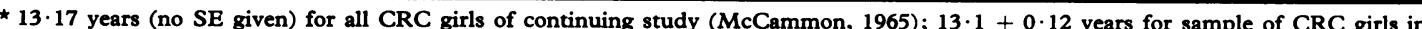
study of initiation of the adolescent spurt (Frisch and Revelle, 1971). 


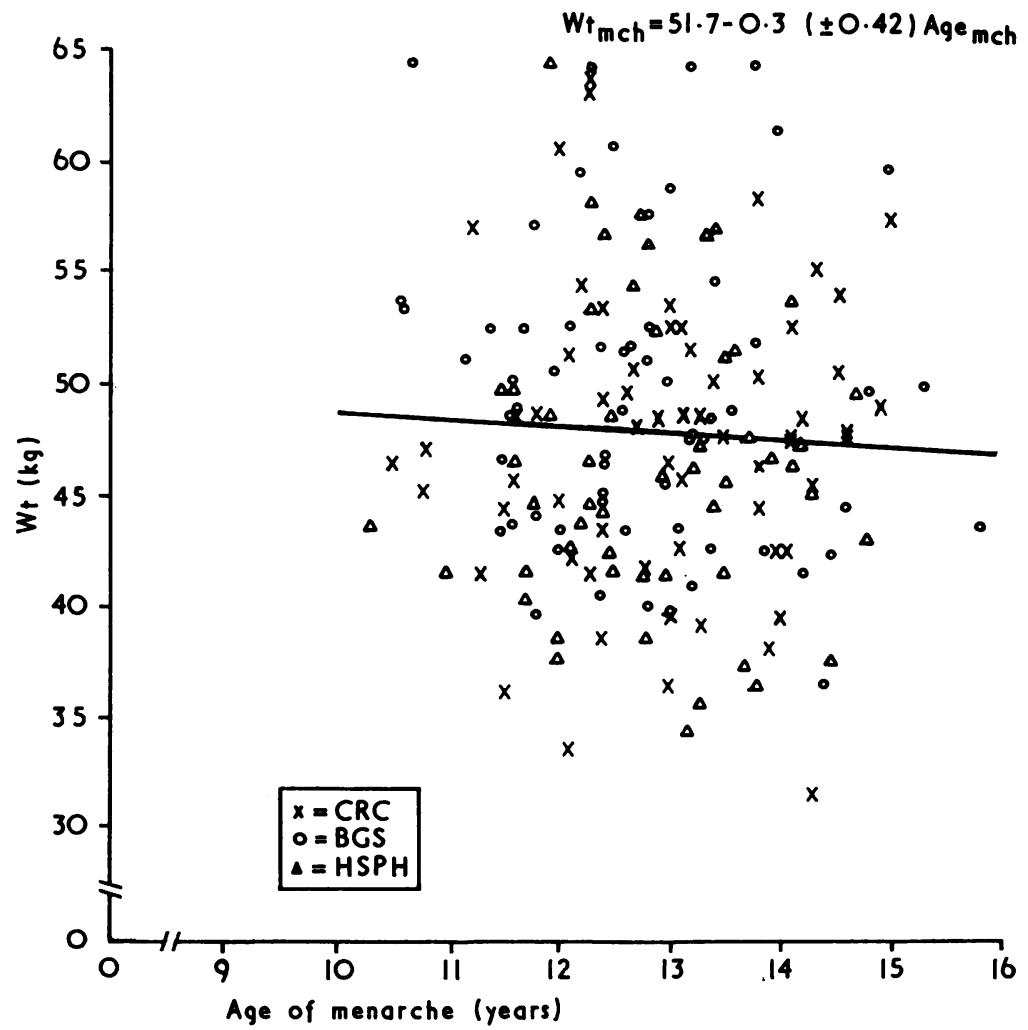

FIG. 1.-Weight at menarche $\left(W t_{m c h}\right)$ vs. age of menarche (Age $\left.e_{m c h}\right)$ for CRC, BGS, and HSPH girls. Slope of regression line of $W t_{m c h}$ on Agemch does not differ significantly from zero $(P>0.50)$.

$47 \cdot 8 \pm 0.51 \mathrm{~kg}, 84 \%$ of their mean weight at age 18. Their mean height at menarche is $158.5 \pm$ $0.50 \mathrm{~cm}, 96 \%$ of their mean height at age 18 . The mean weight does not change as menarcheal age increases, whereas mean height increases significantly $(P<0.02)$ (Table I, Fig. 1 and 2). (If HSPH girls, who we know from Frisch and Revelle, $1969 \mathrm{~b}$, include unusually short latest maturers, are excluded, the means of the earliest and latest maturers are $156 \cdot 7 \pm 1 \cdot 2 \mathrm{~cm}$ and $162 \cdot 1 \pm 1 \cdot 6 \mathrm{~cm}$ $[P<0.01]$ respectively.)

Centiles of height and weight at menarche are given in Table II. Weight does not vary within the 25,50 , or 75 centiles with increasing age, i.e. the distribution of weights around an invariant mean is the same for each age group (also Fig. 1). Centiles of weight, therefore, can be given for all age groups combined.

TABLE II

Centiles of Height and Weight at Menarche for BGS, CRC, and HSPH Girls

\begin{tabular}{|c|c|c|c|c|c|c|c|}
\hline \multirow{2}{*}{$\begin{array}{c}\text { Menarcheal } \\
\text { Age Group } \\
\text { (yr) }\end{array}$} & \multirow{2}{*}{ No. } & \multicolumn{3}{|c|}{ Weight (kg) } & \multicolumn{3}{|c|}{ Height $(\mathrm{cm})$} \\
\hline & & 25 & 50 & 75 & 25 & 50 & 75 \\
\hline $\begin{array}{l}\text { Up to and including } 11 \cdot 9 \\
12 \cdot 0-12 \cdot 9 \\
13 \cdot 0-13 \cdot 9 \\
14 \cdot 0 \text { and over }\end{array}$ & $\begin{array}{l}35 \\
60 \\
54 \\
32\end{array}$ & $\begin{array}{l}43 \cdot 7 \\
42 \cdot 6 \\
42 \cdot 6 \\
42 \cdot 8\end{array}$ & $\begin{array}{l}47 \cdot 0 \\
48 \cdot 5 \\
47 \cdot 4 \\
47 \cdot 6\end{array}$ & $\begin{array}{l}51 \cdot 0 \\
53 \cdot 4 \\
51 \cdot 3 \\
50 \cdot 2\end{array}$ & $\begin{array}{l}152 \cdot 7 \\
154 \cdot 7 \\
155 \cdot 6 \\
-\star\end{array}$ & $\begin{array}{l}155 \cdot 9 \\
159 \cdot 3 \\
159 \cdot 7 \\
160 \cdot 0\end{array}$ & $\begin{array}{l}161 \cdot 7 \\
162 \cdot 1 \\
163 \cdot 8 \\
166 \cdot 9\end{array}$ \\
\hline All subjects & 181 & $43 \cdot 0$ & $47 \cdot 7$ & $51 \cdot 5$ & & & \\
\hline
\end{tabular}

*See text. 


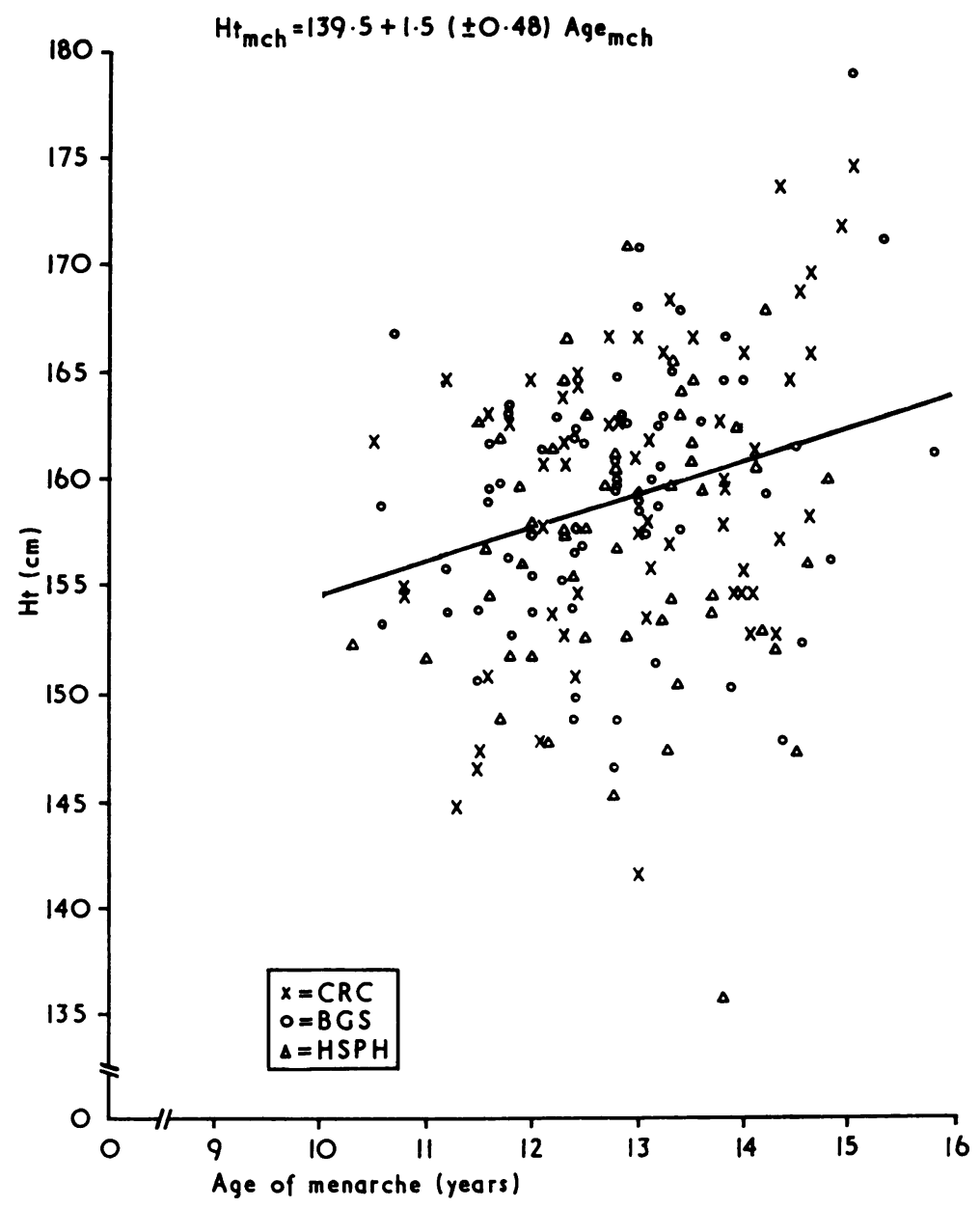

FIG. 2.-Height at menarche $\left(H t_{m c h}\right)$ vs. age of menarche for $C R C, B G S$, and $H S P H$ girls. Slope of regression line of $H t_{m c h}$ on Age $e_{m c h}$ differs significantly from zero $(P<0 \cdot 01)$.

Table II also shows that the major differences in height with increasing menarcheal age after 12 years seem to be in the 25 and 75 centiles, though numbers in each centile are too small to be conclusive. If the effect is real, girls in the 50 centile, after menarcheal age 11.9 years, apparently attain menarche at essentially the same mean height, in addition to the same mean weight.

Early and late menarcheal girls (grouped by age of menarche) gain the same amount of height, about $22 \mathrm{~cm}$, and the same amount of weight, about $17 \mathrm{~kg}$, in the interval from the initiation of the adolescent spurt to menarche (Table III). This result is especially interesting since late maturers grow more slowly than early maturers during the adolescent spurt (Simmons and Greulich, 1943;
Shuttleworth, 1937, 1939), including, as we found, the year of menarche: in that year the mean increments in height and weight growth are 7.0 \pm 0.24 $\mathrm{cm}$ and $6 \cdot 8 \pm 0.46 \mathrm{~kg}$, respectively, for girls, with a mean age of menarche of 11.4 years, decreasing gradually to $3.8 \pm 0.21 \mathrm{~cm}$ and $4 \cdot 2 \pm 0.35 \mathrm{~kg}$, respectively, for girls with a mean age of menarche of 14.5 years (differences significant at $P<0.01$ (Table IV)). As expected, because of the difference in growth rates, the mean time interval between the initiation of the growth spurt and menarche is about 8 months longer for late maturers than for early maturers (Frisch and Revelle, 1971) (Table III).

At age 18, when growth in height has ceased for all girls (Frisch and Revelle 1969b), early and late 
TABLE III

Mean Height and Weight Gained, and Mean Time Intervals from Age of Initiation of Height (age $H_{i}$ ) and Weight (age $W_{i}$ ) Spurts, Respectively to Age of Menarche (age mch) for CRC, BGS, and HSPH Girls Grouped According to Age of Menarche

\begin{tabular}{|c|c|c|c|c|c|}
\hline \multirow{2}{*}{$\underset{(y r)}{\text { Menarcheal Age Group }}$} & \multirow{2}{*}{ No. } & \multicolumn{4}{|c|}{ Mean $\pm \mathrm{SE}$} \\
\hline & & $\begin{array}{c}\mathbf{H}_{\text {moh }} \text { Less } \mathbf{H}_{\mathbf{i}} \\
(\mathrm{cm})\end{array}$ & $W_{\text {moh Less }} W_{(\mathbf{k g})}$ & $\begin{array}{l}\text { Age Mch Less } \\
\text { Age } \mathrm{H}_{\mathbf{i}}(\mathrm{yr})\end{array}$ & $\begin{array}{l}\text { Age Mch Less } \\
\text { Age } W_{i}(y r)\end{array}$ \\
\hline $\begin{array}{l}\text { Up to and including } 11 \cdot 9 \\
12 \cdot 0-12 \cdot 9 \\
13 \cdot 0-13 \cdot 9 \\
14 \cdot 0-14 \cdot 9\end{array}$ & $\begin{array}{l}31 \\
55 \\
52 \\
31\end{array}$ & $\begin{array}{l}21 \cdot 6 \pm 0.97 \\
21 \cdot 3 \pm 0.79 \\
22 \cdot 8 \pm 0.63 \\
21 \cdot 1 \pm 0.94\end{array}$ & $\begin{array}{l}16.8 \pm 0.90 \\
17.6 \pm 0.78 \\
16.7 \pm 0.58 \\
16.9 \pm 0.92\end{array}$ & $\begin{array}{l}2 \cdot 8 \pm 0 \cdot 13 \\
3 \cdot 1 \pm 0 \cdot 12 \\
3 \cdot 5 \pm 0 \cdot 10 \ddagger \\
3 \cdot 5 \pm 0 \cdot 14 \ddagger\end{array}$ & $\begin{array}{l}2 \cdot 9 \pm 0 \cdot 14 \\
3 \cdot 3 \pm 0 \cdot 11^{\star} \\
3 \cdot 4 \pm 0 \cdot 13 \dagger \\
3 \cdot 7 \pm 0 \cdot 18 \ddagger\end{array}$ \\
\hline \multirow[t]{2}{*}{$\begin{array}{l}\text { All subjects } \\
\text { CRC } \\
\text { BGS } \\
\text { HSPH }\end{array}$} & $\begin{array}{l}56 \\
61 \\
52\end{array}$ & $\begin{array}{l}22 \cdot 5 \pm 0 \cdot 70 \\
22 \cdot 3 \pm 0 \cdot 72 \\
20 \cdot 7 \pm 0 \cdot 68\end{array}$ & $\begin{array}{l}16.9 \pm 0.71 \\
17.5 \pm 0.68 \\
16.8 \pm 0.65\end{array}$ & $\begin{array}{l}3.4 \pm 0.10 \\
3.3 \pm 0.11 \\
3.1 \pm 0.11\end{array}$ & $\begin{array}{l}3 \cdot 3 \pm 0.13 \\
3 \cdot 4 \pm 0 \cdot 11 \\
3 \cdot 3 \pm 0.11\end{array}$ \\
\hline & 169 & $21.9 \pm 0.41$ & $17 \cdot 1 \pm 0.39$ & $3 \cdot 3 \pm 0.06$ & $3 \cdot 3 \pm 0.07$ \\
\hline
\end{tabular}

*Difference from earliest group significant at $P<0.05$.

$\dagger$ Difference from earliest group significant at $P<0.02$.

$\ddagger$ Difference from earliest group significant at $\mathbf{P}<0 \cdot 01$.

TABLE IV

Mean Increments Gained During Year of Menarche by CRC, BGS, and HSPH Girls Grouped According to Age of Menarche

\begin{tabular}{l|c|c|c}
\hline $\begin{array}{c}\text { Menarcheal } \\
\text { Age } \\
\text { Group }\end{array}$ & No. & $\begin{array}{c}\text { Mean Height } \\
\text { Increment } \pm \text { SE } \\
(\mathrm{cm})\end{array}$ & $\begin{array}{c}\text { Mean Weight } \\
\text { Increment } \pm \text { SE } \\
(\mathrm{kg})\end{array}$ \\
\hline Up to 11.9 & 35 & $7 \cdot 0 \pm 0 \cdot 24$ & $6 \cdot 8 \pm 0 \cdot 46$ \\
$12 \cdot 0-12.9$ & 60 & $5 \cdot 7 \pm 0 \cdot 15^{\star}$ & $5 \cdot 5 \pm 0 \cdot 27 \dagger$ \\
$13 \cdot 0-13.9$ & 54 & $4 \cdot 3 \pm 0 \cdot 22^{\star}$ & $4 \cdot 8 \pm 0 \cdot 27^{\star}$ \\
$14 \cdot 0-14.9$ & 32 & $3 \cdot 8 \pm 0 \cdot 21^{\star}$ & $4 \cdot 2 \pm 0 \cdot 35^{\star}$ \\
\hline
\end{tabular}

* Difference from earliest group significant at $\mathbf{P}<0.01$.

+ Difference from earliest group significant at $\mathbf{P}<0.02$.

menarcheal girls are the same height (Table I) (Frisch and Revelle, 1969b, 1971; Boas, 1932; Richey, 1937), but late maturers are lighter in weight (Table I) (Frisch and Revelle, 1969b, 1971; Shuttleworth, 1937) and remain so into adulthood (Tanner, 1962; Frisch and Revelle, 1969b).

The CRC girls from Denver (altitude $1610 \mathrm{~m}$ ) attain menarche at a mean weight which does not differ significantly from that of the BGS or HSPH girls (sea level) (Table I), but the CRC girls' mean age of menarche is later (Table $\mathrm{I}$ ), as has been found for other girls living at high altitudes (Valšík, Štukovský, and Bernátová, 1963; Valšík, 1965).

The mean height and weight gained by the CRC girls from initiation of the adolescent spurt to menarche and the mean duration of their spurt do not differ significantly from that of the BGS girls (Table III).
Experiments with animals have shown that the age 'at puberty' is related more to body weight than to chronological age (Widdowson and McCance, 1960; Kennedy and Mitra, 1963). In man, Donovan and van der Werff ten Bosch (1965) point out that it is likely that the current secular trend to an earlier age of onset of puberty is 'secondary to an acceleration in body development'.

Based on our findings of an unvarying mean weight at menarche, we propose that there is a direct relation between body weight and menarche. A possible mechanism for such a relation was suggested by Kennedy and Mitra (1963) to explain their findings of the close relation of weight and first oestrus and mating in the rat. Our adaptation of this mechanism to explain menarche assumes that the attainment of the critical weight (a range around it is presupposed) causes a change in metabolic rate, which, in turn, affects the hypothalamus-ovarian feedback by decreasing the sensitivity of the hypothalamus to oestrogen. The feedback is then reset at a level of gonadotrophins and gonadal hormones high enough to induce the ovarian and uterine maturation resulting in menarche.

Weight is considered a good measure of 'metabolic size' in the normal child (Cheek et al., 1969). That early and late maturing girls gain the same mean amount of weight from initiation of the adolescent spurt to menarche despite differences in rates of growth, supports the idea of attainment of a particular metabolic size preceding menarche. 
It also may be significant that two other adolescent events, initiation of the adolescent spurt and attainment of maximum rates of growth, take place for boys at mean weights 6 and $8 \mathrm{~kg}$ heavier, respectively, than that for girls (and two years later), but these weights are equivalent to the same average metabolic rate (cal/kg per day computed from Talbot's standards [Talbot, 1938]) for each sex at each event (Frisch and Revelle, 1969b, 1971). (The consistent weight and time difference between boys and girls at each adolescent event suggests that there may be a stage of sexual maturation in boys comparable to menarche in girls occurring at a weight of about $55 \mathrm{~kg}$ at a mean age of $14 \cdot 9$ years.)

Whatever the mechanism, the assumption that a critical body weight triggers menarche, can explain simply many unexplained observations associated with a late menarche. All such observations have in common that growth is slowed prenatally, postnatally, or both, so that the critical weight is reached at a later age: malnutrition delays menarche (Dreizen, Spirakis and Stone, 1967; Frisch and Revelle, 1969a); altitude delays menarche (Valšík et al., 1963; Valšik, 1965) (though the estimate of three months per $100 \mathrm{~m}$ must be an error; per $1000 \mathrm{~m}$ is reasonable); twins have later menarche than singletons of the same population (TisserandPerrier, 1953); later born sibs in a family have later menarche-they are smaller in height and weight than earlier sibs (Tanner, 1966).

Conversely, observations of earlier menarche are associated with attaining the critical weight more quickly: obese girls have menarche earlier than the average age (Donovan and van der Werff ten Bosch, 1965); and most important, the secular trend to an earlier menarche, about three to four months per decade in Europe in the last hundred years, is associated with an increase in height and weight such that children of 11 at present are as large as children of 12,30 or 40 years ago (Tanner, 1966).

During the interval from spurt initiation to menarche, the growth of the CRC girls was apparently not slowed by altitude: they gained the same amount of height and weight in the same mean time as the BGS girls. Since the mean birthweight of the CRC girls was significantly lighter than that of the BGS girls, and the CRC girls grew more slowly from birth to initiation of the spurt (Frisch and Revelle, 1970, 1971), this finding suggests that growth during the adolescent spurt is controlled differently, or is somehow less affected by altitude, than is the intrauterine and childhood growth before the spurt.
Another possible explanation of this result is that postuterine growth up to adolescence is not affected directly by altitude but is 'imprinted' by the earlier intrauterine retardation (Gifford et al., 1966) caused by altitude, in the same manner in which limitation of food in the weaning period affects later growth in the rat, or a closer analogy, in the way intrauterine deprivation may affect subsequent growth rate in the pig (Widdowson and McCance, 1960). Adolescent growth may be independent of such 'imprinting'.

The critical weight-menarche hypothesis and the proposed explanation of the secular trend could be tested by comparing the weights of girls at menarche in this decade with the estimate of $48 \mathrm{~kg}$ two or three decades ago. Both would be supported if the mean weight at menarche has not changed while the age of menarche has become earlier. According to our hypothesis also, the secular trend to an earlier menarche should end when the weight of children of successive cohorts remains the same because of the attainment of maximum nutrition and child care.

The simple, but potentially interesting, measurement of weight at menarche could be obtained in prospective studies of menarche and ongoing growth studies.

We thank Mrs. Sole Cook for her assistance with the statistical computations.

\section{REFERENCES}

Boas, F. (1932). Studies in growth. Human Biology, 4, 307.

Cheek, D. B., Graystone, J. E., Mellits, E. D., and Reba, R. C. (1969). Body composition: anthropometric growth and heat production. In Adolescent Nutrition and Growth, p. 163. Ed. by F. P. Heald. Appleton-Century-Crofts, New York; Butterworths, London.

Donovan, B. T., and van der Werff ten Bosch, J. J. (1965). Physiology of Puberty, p. 31. Williams and Wilkins, Baltimore; Arnold, London.

Dreizen, S., Spirakis, C. N., and Stone, R. E. (1967). A comparison of skeletal growth and maturation in undernourished and well-nourished girls before and after menarche. Fournal of Pediatrics, 70, 256.

Dunlop, D. G. (1943). The families of the Child Research Council. Fournal of Pediatrics, 22, 111.

Frisch, R. E., and Revelle, R. (1969a). Variation in body weights and the age of the adolescent growth spurt among Latin American and Asian populations, in relation to calorie supplies. Human Biology, 41, 185.

Frisch, R. E., and Revelle, R. (1969b). The height and weight of adolescent boys and girls at the time of peak velocity of growth in height and weight: longitudinal data. Human Biology, 41, 536.

Frisch, R. E., and Revelle, R. (1970). Height and weight at menarche and a hypothesis of critical body weights and adolescent events. Science, 169, 397.

Frisch, R. E., and Revelle, R. (1971). The height and weight of girls and boys at the time of initiation of the adolescent growth spurt in height and weight and the relationship to menarche. Human Biology, 43, 140.

Gifford, S., Murawski, B. J., Brazelton, T. B., and Young, G. C. (1966). Differences in individual development within a pair of identical twins. International fournal of Psycho-Analysis, 47, 261 . 
Kennedy, G. C., and Mitra, J. (1963). Body weight and food intake as initiating factors for puberty in the rat. Fournal of Physiology, 166, 408.

McCammon, R. W. (1965). Are boys and girls maturing physically at earlier ages? American fournal of Public Health and the Nation's Health, 55, 103.

Marshall, W. A., and Tanner, J. M. (1968). Growth and physiological development during adolescence. Annual Review of Medicine, 19, 283.

Richey, H. G. (1937). The relation of accelerated, normal and retarded puberty to the height and weight of school children. Monographs of the Society for Research in Child Development, 2 (1).

Shuttleworth, F. (1937). Sexual maturation and the physical growth of girls age 6 to 19 . Monographs of the Society for Research in Child Development, 2 (5).

Shuttleworth, F. K. (1939). The physical and mental growth of girls and boys age 6 to 19 in relation to age at maximum growth. Monographs of the Society for Research in Child Development, 4 (3).

Simmons, K., and Greulich, W. W. (1943). Menarcheal age and the height, weight, and skeletal age of girls age 7 to 17 years. Fournal of Pediatrics, 22, 518.

Stuart, H. C., Reed, R. B. et al. (1959). Child health and development (Longitudinal studies). Pediatrics, 24, 875.
Talbot, F. B. (1938). Basal metabolism standards for children. American fournal of Diseases of Children, 55, 455.

Tanner, J. M. (1962). Growth at Adolescence, 2nd ed., p. 95. Blackwell, Oxford.

Tanner, J. M. (1966). The secular trend towards earlier physical maturation. Tijdschrift voor Sociale Geneeskunde, 44, 524.

Tisserand-Perrier, M. (1953). Etude comparative de certains processus de croissance chez les jumeaux. Fournal de Génétique Humaine, 2, 87.

Tuddenham, R. D., and Snyder, M. M. (1954). Physical growth of California boys and girls from birth to eighteen years. University of California Publications in Child Development, 1 (2).

Valšik, J. A. (1965). The seasonal rhythm of menarche. Human Biology, 37, 75 .

Valšik, J. A., Stukovský, R., and Bernátová, L. (1963). Quelques facteurs géographiques et sociaux ayant une influence sur l'âge de la puberté. Biotypologie, 24, 109.

Widdowson, E. M., and McCance, R. A. (1960). Some effects of accelerating growth. I. General somatic development. Proceedings of the Royal Society. Series B. Biological Sciences, 152, 188.

Correspondence to Dr. R. E. Frisch, Harvard Center for Population Studies, 9 Bow Street, Cambridge, Massachusetts 02138, U.S.A. 